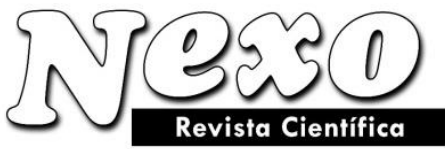

ISSN-E 1995-9516

Universidad Nacional de Ingeniería COPYRIGHT @ (UNI). TODOS LOS DERECHOS RESERVADOS

http://revistas.uni.edu.ni/index.php/Nexo https://doi.org/10.5377/nexo.v33i02.10765

\title{
Evaluating the degree of physical resilience of Babol against earthqakes
}

\section{Evaluación del grado de resiliencia física de Babol contra los terremotos}

\author{
Mehdi Zare $^{1, *}$, Morteza Shojaei ${ }^{1}$, Bahram Akasheh $^{2}$, Abbas Ostadtaghizadeh $^{2}$, Arezo Dorostian ${ }^{1}$ \\ 1 Department of Geophysics, North Tehran Branch, Islamic Azad University, Tehran,Iran. \\ 2 Department of Health in Emergencies and Disasters, School of Public Health, University \\ of Medical Sciences, Tehran,Iran.
}

*Corresponding author email: $\underline{\text { mzare@ iiees.ac.ir }}$

(recibido/received: 14-May-2020; aceptado/accepted: 18-June-2020)

\begin{abstract}
The management of natural disasters requires understanding their essence, making accurate assessments, planning, and providing appropriate solutions. The purpose of this study is to evaluate the physical resilience of the 22 neighborhoods of Babol located in the north of Iran against earthquakes. The methodology of this applied research study is descriptive-analytical. In this regard, by initially studying similar national and international studies, using the expert opinion of seismology and urban planning specialists and interviewing experienced urban managers in the field of crisis management, 30 effective indices on physical resilience against earthquake risk were extracted. Then, using analytic functions of GIS software and multi-criteria models including AHP, TOPSIS, VIKOR and COPRAS, the physical resilience of Babol against earthquakes was evaluated. Then, in order to obtain accurate results, using the integration models including the Statistic, BORDA and COPELAND, the physical resilience of Babol's 22 neighborhoods was evaluated. The analysis of the final GIS maps shows that neighborhoods $2,3,4,5$, and 11 have very high physical resilience and neighborhoods $6,8,10,12$ and 14 have very low physical resilience against earthquakes.
\end{abstract}

Keywords: physical resilience, earthquake, Babol, multi-criteria decision-making model, integration model.

\section{RESUMEN}

La gestión de desastres naturales requiere comprender su esencia, realizar evaluaciones precisas, planificar y brindar soluciones adecuadas. El propósito de este estudio es evaluar la resiliencia física de los 22 barrios de Babol ubicados en el norte de Irán frente a terremotos. La metodología de este estudio de investigación aplicada es descriptiva-analítica. En este sentido, mediante el estudio inicial de estudios similares nacionales e internacionales, utilizando la opinión experta de especialistas en sismología y planificación urbana y entrevistando a gestores urbanos experimentados en el campo de la gestión de crisis, se extrajeron 30 índices efectivos de resiliencia física frente al riesgo sísmico. Luego, utilizando 
funciones analíticas de software GIS y modelos multicriterio incluyendo AHP, TOPSIS, VIKOR y COPRAS, se evaluó la resiliencia física de Babol frente a terremotos. Luego, con el fin de obtener resultados precisos, utilizando los modelos de integración incluyendo la Estadística, BORDA y COPELAND, se evaluó la resiliencia física de los 22 barrios de Babol. El análisis de los mapas GIS finales muestra que los barrios 2, 3, 4, 5 y 11 tienen una resistencia física muy alta y los barrios 6, 8, 10, 12 y 14 tienen una resistencia física muy baja frente a los terremotos.

Palabras clave: resiliencia física, terremoto, Babol, modelo de toma de decisiones multicriterio, modelo de integración.

\section{INTRODUCTION}

Cities are integrated and interdependent systems that are vulnerable to threats caused by natural and human disasters. Specific physical and architectural features, high population densities, and intensive and complex infrastructural systems have increased the vulnerability of the city to earthquakes, floods and storm hazards. With the global warming process, the recurrence of natural disasters is a serious challenge for the sustainable development of communities. Therefore, emergency decision-making (EDM) for natural disasters plays an important role in improving the ability to deal with natural disasters (Zhou et al, 2018). A crisis is an incident that is associated with widespread physical and financial damages or causes of such damages that requires urgent action. These kinds of natural disasters leading to critical situations in society are often potentially dangerous, devastating and fatal (Alexander, 2000). Today, there is a significant shift in attitudes towards natural hazards globally, with the prevailing focus shifting from reducing vulnerability to increasing resilience to disasters. According to this view, risk reduction programs should seek to create and enhance the characteristics of resilient communities and address the concept of resilience in the disaster management chain (Cutter et al ,2008). The attitude towards resilience and its analysis plays a key role in understanding resilience and its causes on the one hand and affects its risk reduction policies and practices and how to deal with them. In fact, this approach is aimed at reducing the vulnerability of cities and enhancing citizens' ability to cope with the dangers of threats such as natural disasters (Mitchell and Harris , 2012).

The statistics show that about $95 \%$ of all natural disasters in the world occur in developing countries, which is about twenty times more than developed countries (Krimer et al , 2003). Over the past ten years, natural disasters have affected more than 1.5 billion people around the world. The effects of these incidents include loss of life, damage, property damage and disruption of infrastructure, as well as social, economic and environmental damage (Hemingway and Gunawan , 2018 ). This issue becomes more important when it comes to knowing that in recent years the crises have caused losses of approximately $\$ 600$ billion to countries, and about 750,000 fatalities (Birkman , 2006). To confront this situation, in 2005 the United Nations (UN) International Strategy for Disaster Reduction Hyogo World Conference in Japan launched a program entitled "Strengthening the nations and communities resilience against disasters in 2005-2015". In addition to reducing the vulnerability of communities in times of crisis, this program tends to increase and improve the resilience of communities (Mayunga , 2007). In recent decades, the growing population of Iran, and the migration from the villages have led to the rapid growth of cities. In such situations, where the sustainable development of the cities of the country has been possible, the problems of urbanization have emerged as a sensitive and important issue (Zangiabadi et al ,2013). Considering the fact that Iran is located in the Alps-Himalayas earthquake belt, it is considered as one of the young and orogenic parts of the world and is one of the earthquake-prone countries (Ahmadiyani et al , 2010). 


\section{RESEARCH OBJECTIVES AND QUESTIONS}

Due to the proximity of Babol city to the active and earthquake-prone of north Alborz and the Caspian faults, the seismicity of the city and the location of old and dense urban fabric in the central neighborhoods, the presence of unauthorized and inefficient housing with low passage widths in the margin of the city and the low quality of building materials in these neighborhoods have caused about $34 \%$ of Babol's neighborhoods to have poor physical earthquake resilience. Therefore, the main purpose of this study was to analyze the physical indices in resilience and classifying the 22 neighborhoods of Babol against earthquakes. According to the stated objectives, the main questions of this research are as follows:

1. What is the situation of Babol's 22 neighborhoods in terms of physical resilience?

2. What is the situation of each of the studied neighborhoods relative to each other?

\section{RESEARCH METHOD}

Considering the fact that this research has an applied purpose and is based on a descriptive-analytical method, the national and international studies selected were carried out in the area of resilience of communities against natural disasters. Subsequently, articles evaluating physical resilience and effective indices of physical resilience were evaluated. Then, 25 experts including university professors specialized in earthquakes, urban planning, civil engineering, as well as managers in the urban area and crisis management were interviewed.

In this interview, 30 important and influential indices of physical resilience to earthquakes in the 22 neighborhoods of Babol were extracted. In order to evaluate, a multi-criteria decision making model including Analytic Hierarchy Process (AHP), TOPSIS, VIKOR and COPRAS was used as follows. At first, the weight of the 30 indices was ranked between 1 and 9 by AHP and the paired comparison matrix by 16 experienced and long-time professionals including university professors in the field of urban and executive management. Then, using method TOPSIS, VIKOR and COPRAS, the 22 neighborhoods of Babol were ranked in terms of physical resilience. After extracting the coefficient and ranking tables, the resilience of the 22 neighborhoods was classified and finally, using GIS software, the resilience of these neighborhoods was plotted. Since the ranking of neighborhoods by the three above models may differ, to achieve the final ranking, the integration model is used with the Statistic, BORDA and COPELAND. After categorizing the indices by the three methods, the prioritization results are combined and their mean is obtained for each neighborhood. In the end, each neighborhood is ranked according to the results of the integration method and the final rank of each neighborhood in the area of physical resilience is achieved. Using the GIS software, the resilience neighborhoods are mapped based on the final integration model and the resilience of the twelve neighborhoods of Babol are compared.

\section{THE SCOPE OF STUDIED AREA}

Babol as the second most populated city of Mazandaran province in northern Iran, located at $36^{\circ} 33^{\prime} 05^{\prime \prime} \mathrm{N}$ $52^{\circ} 40^{\prime} 44^{\prime \prime} \mathrm{E}$, being one of the major cities of northern Iran in agriculture, academics, business and medical services. This city is situated between the Caspian Sea and the Alborz mountain range and $210 \mathrm{~km}$ northeast of Tehran. The total area of Babol is about 3258 hectares, with a population of 250,217 people 
and a relative density of 7680 people per square kilometer according to the 2016 census. The city is divided into 2 urban areas and 22 neighborhoods.

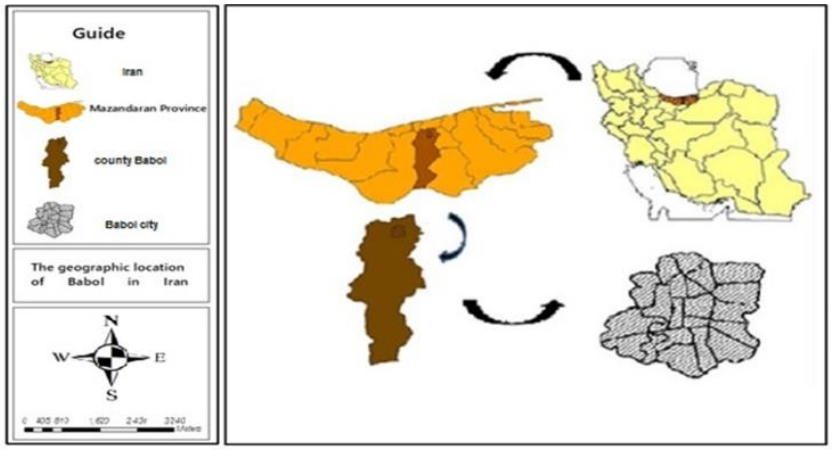

Figure 1. Location of the studied area

\section{RESEARCH PRINCIPLES}

In the last century, due to the variety of natural and human hazards, many damages have been caused to the environment and cities. Today, the analysis and increase of resilience against the reduction of vulnerability to natural hazards has become an important and widespread issue in the field of planning and management of global hazards. Earthquakes are one of the hazards that can have many adverse effects on cities and communities that, unlike other hazards, have a very low predictive potential. Reducing the risk of earthquakes and improving the earthquake resilience capacity is a major concern of crisis management officials around the world. Therefore, countries that are prone to earthquakes should make appropriate short and long-term decisions (Robatmili et al , 2018 ).

The importance of natural disasters, in particular the earthquake, is to the extent that in December 1987 the United Nations General Assembly declared the 1990s and 2000s as the International Decade to Reduce Earthquake Impacts.

Cities, as the most complex man-made structures, have always been exposed to natural and human hazards, and these unpredictable dangers have had serious impacts on urban areas (Islamlou and Mirmoghtadaei , 2016). Urban development is directly related to the physical development of cities (Ibrahimzade et al ,2014). Although urban communities can predict some of the consequences of natural and human hazards, many of the effects are unknown and unpredictable (Gunderson , 2010). Therefore, safety against hazards and crises is one of the most basic principles for achieving optimal standards of urban comfort (Mohammadi ; 2014). Thus, planning to reduce earthquake crises has a relatively complex process (Allen , 2007). In recent years, the expansion of urbanization has had adverse consequences on the social aspect of cities. Therefore, the dimensions of urban settlements are becoming more and more complex, and consequently, instability in urban ecosystems has emerged (Ziyari et al , 2012). Evidence shows that earthquake threat is widespread worldwide in urban areas, and this threat is one of the most serious problems in the developing countries (Tucker , 1994). In recent years, most planning has been to counteract and reduce risks. In the meantime, resilience is a new concept that is mostly used in the face of unknowns and uncertainties (Behtash et al ,2013). One of the challenges for achieving a well-defined and accepted definition of the scientific community is the fact that individuals, groups and communities may each have varying degrees of resilience that may be defined in different ways (McEntire et al , 2002). That is because the dynamics and interactions between abrupt changes and resilience resourcing make it clear that resilience of complex systems is not merely resistance to change and preservation of existing 
structures, but, at present, resilience is the capacity of a social system in terms of absorbing disorders, reorganizing and maintaining the same function, structure, identity, and previous feedback (Folke, 2006). The word resilience is derived from the Latin root of Resilio meaning "return to the former" (Klein et al , 2003). and is often used to refer to the past. Holing introduced the concept of resilience in the 1970s for the first time by publishing an article on the resilience and resilience of the ecological systems (Holing , 1973). In other words, resilience refers to the capacity to withstand shocks and return to their original state of operation, or at least, sufficient resilience to prevent failure or even collapse of systems (Omand , 2005). It seems that there is a consensus among researchers that resilience plays an important role in dealing with major and shocking disasters in a society (Kimhi ,2014).

\section{RESEARCH BACKGROUND}

Urban vulnerability to natural hazards such as earthquakes is a function of human behavior. In disasterstricken countries, research into natural disasters began in the early 20th century. In recent years Several models of urban vulnerability have been proposed. (Burton et al.1978, Mitchell et al. 1989, Cutter 1996, Menoni and Pergalani 1996, Menoni 2001).(Rashed and Weeks , 2003). For example: (Godschalk, 2003). with the publication of an article entitled Urban Risk Reduction to create resilient cities with a risk reduction policy, prioritized the development of resilient urban systems and increased collaboration between professional groups involved in urban buildings.(Rose , 2004). in a study entitled defining and measuring economic resilience against earthquakes, concluded that imbalances in economic resilience depend on the behavior of individuals, markets, and macro-regional economies.She also presented major conceptual, operational, and policy-making advances in assessing individual and regional economic resilience to earthquakes.

(Martinelli and Cifani , 2008) in a research entitled Building Vulnerability Assessment and Providing Damage Scenarios for Italian Cities assessed the vulnerability of buildings by using vulnerability assessment models such as the Risk-UE model, and finally presented different scenarios estimated and modeled the damages caused by possible earthquakes. (Carreno et al , 2012) with the publication of an article entitled New methodology for urban seismic risk assessment from a holistic perspective believe, that in order to achieve the performance of seismic risk management, it is necessary to define the risk as potential economic, social, and environmental consequences as a dangerous phenomenon over time, and suggest the fuzzy set theory for measurement of seismic risk. (Berke et al , 2012) in a study entitled Planning for Resilience with a Risk Reduction Approach and Adoption of Accident Law, provided a way in urban resilience studies that planners act to enhance the existing resilience components by adopting the law in the city. (Takewaki , 2013 ) in a research entitled Toward greater building earthquake resilience using concept of critical excitation: A review of sustainable cities and society, It is statedthat if unexpected issues are considered in the design of structures, they can be converted into expected issues and examined in order to update the resilience of buildings against earthquakes .( Meerow et al , 2016) in an article entitled a review of the definition of urban resilience, that resilience has become an important goal of cities today especially in the face of climate change. This paper identifies six concepts of fundamental urban stress and finally proposes a new definition of resilience. (carreno et al , 2017) in a study entitled Comprehensive Disaster Risk Assessment for a Urban Risk Management Program, provided a comprehensive approach to assess the physical, economic and social vulnerability of the earthquake in Manizales, Colombia and the results of this comprehensive action plan are recommended to update disaster risk management action plan for the city.(Mishra and Thing , 2019) with the publication of an 
article entitled Structurl Features for Earthquake-Resistant Load-Bearing Residential Building in Nepal, It is recommended to promote awareness on earthquakes and its possible effects on building structures to house owners, local contractors, and related stakeholders. There have also been numerous studies by Iranian researchers in the context of physical resilience. (Varesi and Akbari, 2012) in a study entitled Investigating Residential Buildings Resilience Hamedan city to Earthquakes, determined the buildings resilience to earthquakes by selecting the population of Hamadan's residential buildings. The findings show that most residential buildings are not resilient to earthquakes in the worn-out texture. (Ghanbari et al , 2013) in a research entitled Assessing the vulnerability of cities to earthquake hazard Case study: Tabriz, fifteen natural and human criteria have been identified using earthquake experts' opinions and a comprehensive systemic approach to the vulnerability of Tabriz to earthquake.

In the end, it was concluded that most of the densely populated areas of Tabriz are exposed to high vulnerability and risk during earthquakes. (Habibi and Javanmardi, 2013) with the publication of an article entitled Urban texture instability analysis and assessment of earthquake vulnerability using AHP and GIS Case study: Sanandaj, using the GIS spatial analysis, AHP method and fuzzy method, the vulnerability of Sanandaj city was studied. The results show that a high percentage of existing buildings in Sanandaj face vulnerability to earthquakes. (Rezaei et al , 2015) in a study entitled Measurement and Evaluation of the Physical Resilience of Urban Community against Earthquake (Case Study: Tehran's Neighborhoods),by identifying the factors and indices affecting the level of resilience, they evaluated the physical resilience of Tehran's neighborhoods by the AHP, paired comparison and prioritization. Due to its feasibility, this method is suggested for other cities.(maleki et al , 2015) in a research entitled Evaluation of Physical Resilience of Cities against Earthquakes Using Programming Model Case Study: Ilam, using the COPRAS and GIS model, the physical resilience of Ilam has been investigated and the results of this research show that about $54.17 \%$ of the city of Ilam is resilient to hazards.

( Sarvar and Kashani , 2016) in an article entitled Physical Vulnerability Assessment of Ahar City against Earthquake Crisis, used15 indicators in three spectra of structural, planning and natural indices. The results show that about $30 \%$ of Ahar's urban built-up areas have moderate to high vulnerability to earthquake and do not provide a proper physical structure for earthquake crisis management. (Shokri , 2017) in a study entitling surveyed the resilience of Babol districts against environmental hazards through questionnaires in 4 dimensions, 16 indices and 31 sub-indices and through VIKOR multivariate decisionmaking model concluded that there is a difference among 12 districts of Babol and about 50\% of the districts in Babol have no and low resilience and only $25 \%$ of the districts are fully resilient in terms of indicators.

\section{RESEARCH DATA AND RESULTS}

The main indices in assessing the degree of physical resilience of each city against natural disasters are defined as the main features and characteristics of that area, each having a definite effect on the resilience of that area. In this section, using the multi-criteria decision making model and their combination with the integrated model, the physical resilience of Babol is addressed against earthquakes.

\section{ANALYTICAL HIERARCHY PROCESS (AHP)}

AHP is a simple, robust and flexible method that is used to make decisions in situations where conflicting decision-making criteria make selecting between options difficult. 
In the first step, for AHP, the hierarchical structure of the subject under discussion should be formed in which the criteria, options and their relationship are shown. In the next step, using the paired comparison of the indices and sub-indices, they are scored between 1 and 9 by experts according to their importance. Table 1 . Weight of the 30 indices of physical resilience by AHP method

\begin{tabular}{|c|c|c|}
\hline Row & Index & Weight \\
\hline 1 & The rate of acceleration applied during & 0.05025 \\
\hline 2 & earthquake & \\
\hline 3 & Distances from hazardous facilities & 0.04198 \\
\hline 4 & Significance of buildings & 0.039902 \\
\hline 5 & Number of hospital beds & 0.038607 \\
\hline 6 & \% of worn texture & 0.038494 \\
\hline 7 & Population density & 0.037977 \\
\hline 8 & Buildings under 10 years of construction & 0.037114 \\
\hline 9 & Number of ambulances & 0.036921 \\
\hline 10 & Number of firefighting vehicles & 0.036540 \\
\hline 11 & \% of the open space area & 0.036287 \\
\hline 12 & Distance from fault & 0.035124 \\
\hline 13 & Building density & 0.034751 \\
\hline 14 & Distance from fire station & 0.034278 \\
\hline 15 & Type of structures and materials & 0.03410 \\
\hline 16 & Availability of crisis management base & 0.032802 \\
\hline 17 & Distances from treatment centers & 0.032608 \\
\hline 18 & Openness of streets above 10 $\mathrm{m}$ & 0.032602 \\
\hline 19 & Vulnerability of the gas network & 0.032392 \\
\hline 20 & Vulnerability of water network & 0.031831 \\
\hline 21 & Availability of security and police centers & 0.031013 \\
\hline 22 & \% of buildings above 5 floors & 0.029723 \\
\hline 23 & Slope of land & 0.029354 \\
\hline 24 & The average width of the passage & 0.027966 \\
\hline 25 & Landslide zone & 0.027154 \\
\hline 26 & Vulnerability of the power grid & 0.026009 \\
\hline 27 & Vulnerability of mobile network & 0.025601 \\
\hline 28 & Riparian zone & 0.025291 \\
\hline 29 & Vulnerability of the telecommunication & 0.022887 \\
\hline 30 & network & 0.018690 \\
\hline & Depth of static water level & \\
\hline 2 & &
\end{tabular}


According to Table 1, the three indices of the rate of acceleration applied during earthquakes, $\%$ of residential texture and distances from hazardous facilities were evaluated by researchers as having the highest value, and depth of static water level, vulnerability of the telecommunication network and riparian zone had the lowest values (Table1).

\section{TOPSIS METHOD}

This technique implies that the chosen option should have the smallest distance from the positive ideal solution (best possible and maximum distance from the negative ideal solution (the worst possible condition)). In this research, to rank the neighborhoods of Babol, 30 indices have been used. Then, to determine the significance of each of these variables, their weight is calculated using Shannon entropy. After weighing each of the indices by the Topsis model, each neighborhood is ranked based on the obtained data.

In the Topsis method, only neighborhood 11 is very resilient. The neighborhood is located in district 1 of Babol with a population of 1809 , including $4.5 \%$ of the city. According to Fig. 2, in this model, neighborhood 6 has low resilience, which comprises $6 \%$ of the total neighborhood area with a population of 14,615. (Figure 2).

Table 2. Coefficient and ranking of neighborhoods based on Topsis decision-making and ranking method.

\begin{tabular}{ccccccccccc}
\hline Neighborhoods & $c+$ & $c-$ & $\begin{array}{c}\text { Final } \\
\text { weight }\end{array}$ & Rank & Neighborhoods & $c+$ & c- & $\begin{array}{c}\text { Final } \\
\text { weight }\end{array}$ & Rank \\
\hline 1 & 0.06868 & 0.084398 & 0.5513 & 11 & 12 & 0.07607 & 0.05923 & 0.4378 & 21 \\
2 & 0.0673 & 0.0889 & 0.5690 & 5 & 13 & 0.06939 & 0.08598 & 0.5534 & 9 \\
3 & 0.06768 & 0.0897 & 0.5701 & 4 & 14 & 0.07276 & 0.07066 & 0.4927 & 19 \\
4 & 0.0632 & 0.09035 & 0.5882 & 2 & 15 & 0.06767 & 0.07542 & 0.5271 & 14 \\
5 & 0.06799 & 0.08967 & 0.5687 & 6 & 16 & 0.06781 & 0.0724 & 0.5166 & 17 \\
6 & 0.09931 & 0.05144 & 0.3412 & 22 & 17 & 0.07273 & 0.072260 & 0.4984 & 18 \\
7 & 0.07114 & 0.086381 & 0.5484 & 13 & 18 & 0.065376 & 0.08670 & 0.5701 & 3 \\
8 & 0.07674 & 0.066391 & 0.4639 & 20 & 19 & 0.072147 & 0.0880 & 0.5497 & 12 \\
9 & 0.0693 & 0.08661 & 0.5554 & 8 & 20 & 0.076447 & 0.0832 & 0.5213 & 15 \\
10 & 0.0690 & 0.07403 & 0.5173 & 16 & 21 & 0.06967 & 0.08566 & 0.5515 & 10 \\
11 & 0.04770 & 0.09183 & 0.6581 & 1 & 22 & 0.06777 & 0.08528 & 0.5572 & 7 \\
\hline
\end{tabular}


Table 3. Resilience of neighborhoods based on Topsis decision-making and ranking method.

\begin{tabular}{cccccccc}
\hline \multirow{2}{*}{ Resilience } & Topsis coefficient & \multicolumn{2}{c}{$\begin{array}{c}\text { Number of } \\
\text { neighborhoods }\end{array}$} & \multicolumn{2}{c}{$\begin{array}{c}\text { Area of } \\
\text { neighborhoods }\end{array}$} & \multicolumn{2}{c}{$\begin{array}{c}\text { Population of } \\
\text { neighborhoods }\end{array}$} \\
\cline { 3 - 8 } & & No & $\%$ & $\mathrm{~m}^{2}$ & $\%$ & People & $\%$ \\
\hline $\begin{array}{c}\text { Very high } \\
\text { resilience }\end{array}$ & $0.5947-0.6581$ & 1 & 4.5 & 1487226 & 4.5 & 1809 & 0.7 \\
$\begin{array}{c}\text { High } \\
\text { resilience }\end{array}$ & $0.5484-0.5947$ & 12 & 54.5 & 17438812 & 53.5 & 131982 & 52.7 \\
\hline $\begin{array}{c}\text { Average } \\
\text { resilience }\end{array}$ & $0.4927-0.5313$ & 6 & 27.2 & 10055157 & 30.8 & 76316 & 30.4 \\
$\begin{array}{c}\text { Low } \\
\text { resilience }\end{array}$ & $0.4378-0.4679$ & 2 & 9 & 1681798 & 5.2 & 25511 & 10.1 \\
\hline $\begin{array}{c}\text { Very low } \\
\text { resilience }\end{array}$ & $0.3412-0.4045$ & 1 & 4.5 & 1931352 & 6 & 14615 & 6 \\
\hline & Total & 22 & 100 & 32594346 & 100 & 250217 & 100 \\
\hline
\end{tabular}

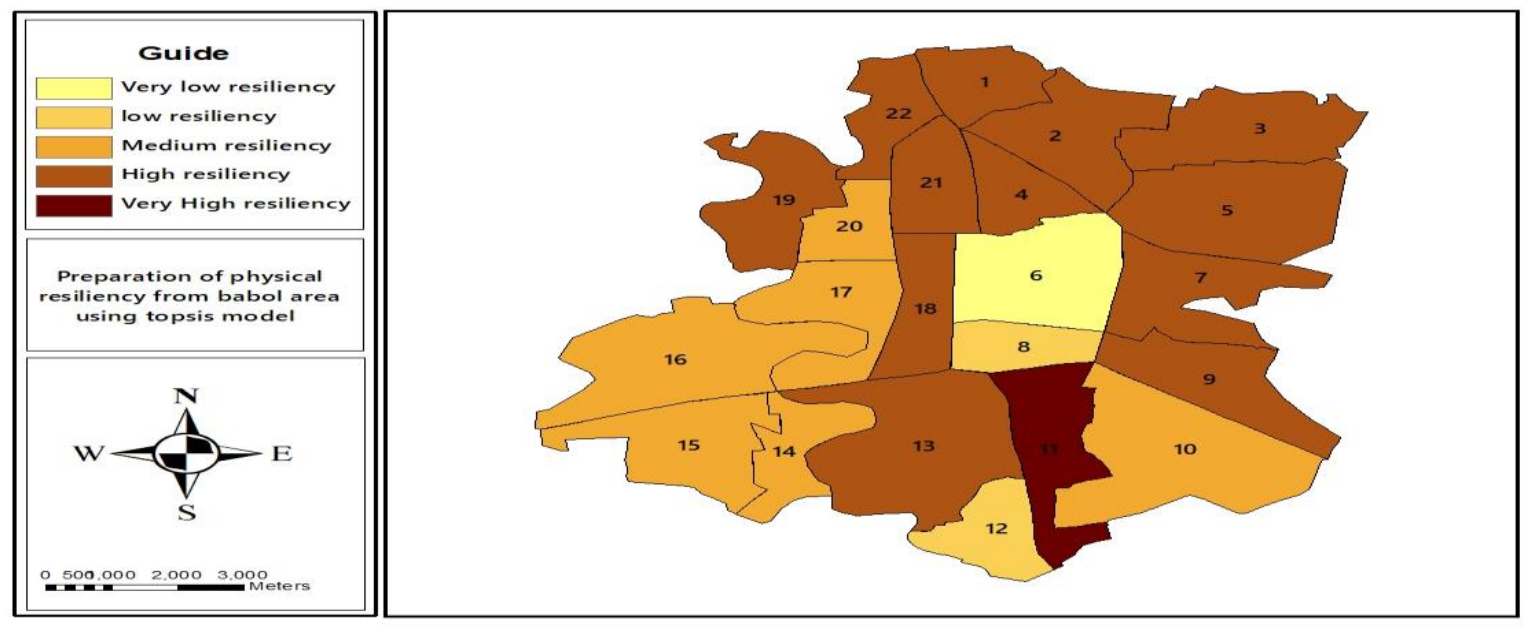

Figure 2. Resilience of neighborhoods based on Topsis decision-making and ranking method

\section{VIKOR METHOD}

The VIKOR method is used to rank various options and is more applicable to solving discrete problems. This approach is based on agreed solutions based on opposite criteria. There are several different options in this model, which are independently evaluated on a multi-criteria basis, and ultimately, the options are ranked based on their value. 
Table 4. Coefficients and rankings of neighborhoods based on VIKOR decision making and ranking method.

\begin{tabular}{cccccccccc}
\hline Rank & $\begin{array}{c}\mathrm{Q} \\
\text { coefficient }\end{array}$ & $\begin{array}{c}\text { Neighbo } \\
\text { rhoods }\end{array}$ & $\begin{array}{c}\mathrm{R} \\
\text { coefficient }\end{array}$ & $\begin{array}{c}\mathrm{S} \\
\text { coefficient }\end{array}$ & Rank & $\begin{array}{c}\mathrm{Q} \\
\text { coefficient }\end{array}$ & $\begin{array}{c}\text { Neighborhoo } \\
\mathrm{ds}\end{array}$ & $\begin{array}{c}\mathrm{R} \\
\text { coefficient }\end{array}$ & $\begin{array}{c}\mathrm{S} \\
\text { coefficient }\end{array}$ \\
\hline 1 & 0.8835 & 3 & 0.1895 & 0.1479 & 12 & 0.6032 & 19 & 0.1794 & 0.1439 \\
2 & 0.8136 & 4 & 0.2164 & 0.1807 & 13 & 0.5788 & 7 & 0.2082 & 0.1578 \\
3 & 0.7855 & 11 & 0.2443 & 0.1988 & 14 & 0.5181 & 15 & 0.1813 & 0.1399 \\
4 & 0.7454 & 18 & 0.2231 & 0.1872 & 15 & 0.4525 & 8 & 0.1835 & 0.1563 \\
5 & 0.7244 & 2 & 0.2802 & 0.1901 & 16 & 0.442 & 10 & 0.1924 & 0.1508 \\
6 & 0.7141 & 5 & 0.1794 & 0.1455 & 17 & 0.4238 & 16 & 0.2039 & 0.1532 \\
7 & 0.6926 & 22 & 0.1895 & 0.1516 & 18 & 0.4155 & 17 & 0.2082 & 0.1604 \\
8 & 0.6808 & 9 & 0.2164 & 0.1457 & 19 & 0.3951 & 14 & 0.1813 & 0.1514 \\
9 & 0.6688 & 13 & 0.2443 & 0.1555 & 20 & 0.3893 & 20 & 0.1835 & 0.1372 \\
10 & 0.6469 & 21 & 0.2231 & 0.1459 & 21 & 0.3474 & 12 & 0.1924 & 0.1517 \\
11 & 0.6167 & 1 & 0.2802 & 0.2001 & 22 & 0.3214 & 6 & 0.2039 & 0.1607 \\
\hline
\end{tabular}

Table 5. Physical resilience of neighborhoods based on VIKOR decision making and ranking method

\begin{tabular}{|c|c|c|c|c|c|c|c|}
\hline \multirow[t]{2}{*}{ Resilience } & \multirow{2}{*}{$\begin{array}{c}\text { VIKOR } \\
\text { coefficient }\end{array}$} & \multicolumn{2}{|c|}{$\begin{array}{c}\text { Number of } \\
\text { neighborhoods }\end{array}$} & \multicolumn{2}{|c|}{$\begin{array}{c}\text { Area of } \\
\text { neighborhoods }\end{array}$} & \multicolumn{2}{|c|}{$\begin{array}{l}\text { Population of } \\
\text { neighborhoods }\end{array}$} \\
\hline & & No & $\%$ & $\mathrm{~m}^{2}$ & $\%$ & People & $\%$ \\
\hline $\begin{array}{l}\text { Very high } \\
\text { resilience }\end{array}$ & $0.785-0.883$ & 3 & 13.6 & 397915 & 12.2 & 19010 & 7.6 \\
\hline High resilience & $0.668-0.745$ & 6 & 27.2 & 100592 & 30.8 & 72187 & 28.8 \\
\hline Average resilience & $0.578-0.646$ & 4 & 18.1 & 488759 & 15 & 42594 & 17 \\
\hline Low resilience & $0.452-0.518$ & 2 & 9 & 440402 & 13.5 & 23744 & 9.5 \\
\hline $\begin{array}{l}\text { Very low } \\
\text { resilience }\end{array}$ & $0.321-0.442$ & 7 & 31.8 & 926428 & 28.4 & 92698 & 37 \\
\hline Total & & 22 & 100 & 325943 & 100 & 250217 & 100 \\
\hline
\end{tabular}

In the VIKOR method, according to Figure 3, neighborhoods 3, 4 and 11 have a very high resilience, accounting for $13.64 \%$ of the total area with a population of 19,0010 , which includes $12.2 \%$ of the total area of Babol. Neighborhoods 10, 16, 17, 14, 20, 12, and 12 have very low resilience, respectively. The seven neighborhoods have 92698 inhabitants, which comprise about 28.4 percent of Babol's area. (Figure3). 


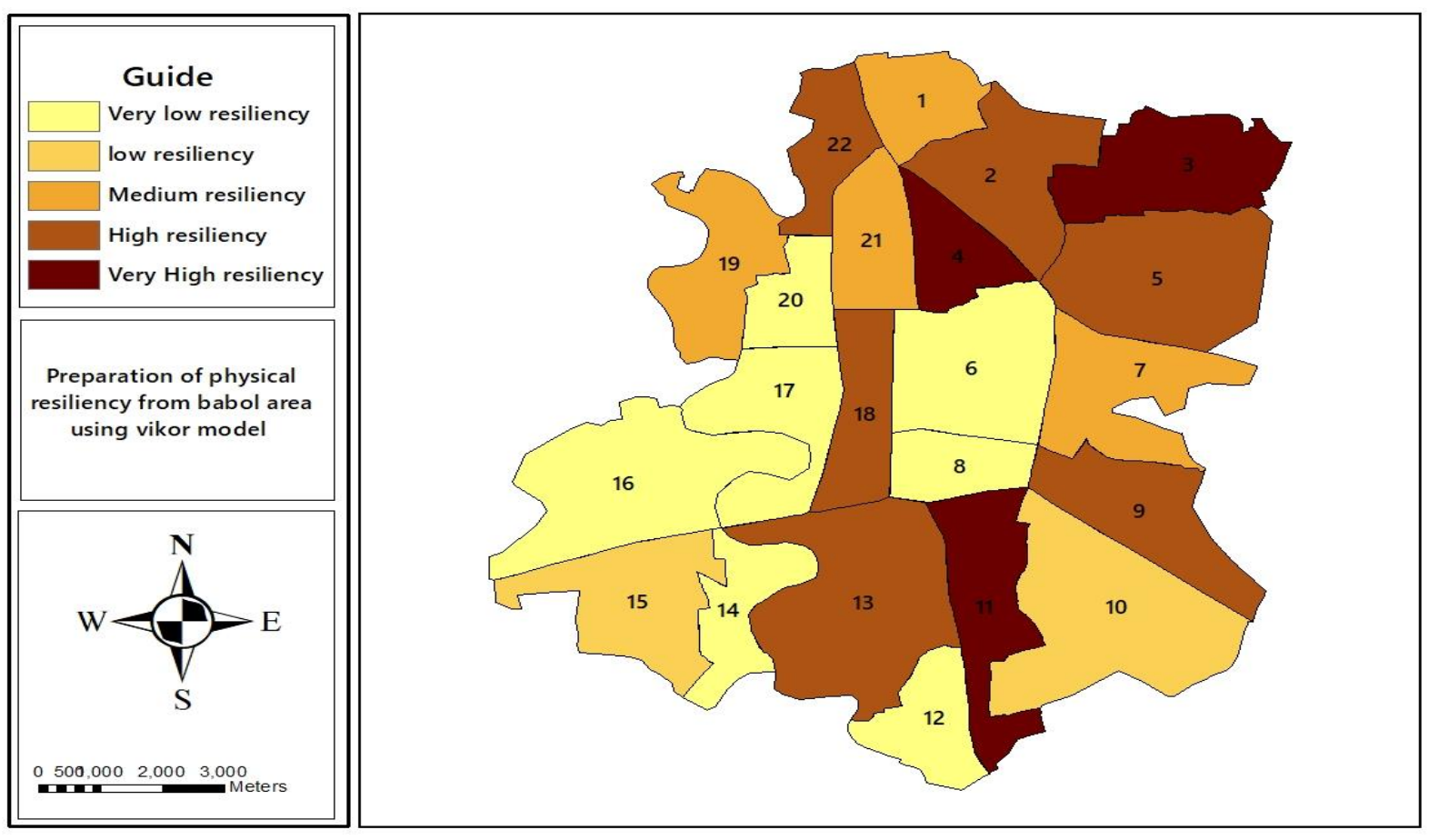

Figure 3. Physical resilience of neighborhoods based on VIKOR decision-making and ranking method

\section{COPRAS METHOD}

The final step is to identify an alternative with the best situation among the criteria, in which the degree of importance of each variable increases or decreases with the rank of each variable.

Table 6. Coefficients and rankings of neighborhoods based on COPRAS decision making and ranking method.

\begin{tabular}{|c|c|c|c|c|c|c|c|}
\hline Neighborhoods & $\begin{array}{c}\text { Relative } \\
\text { Importance of } \\
\text { Options (Qi) }\end{array}$ & $\begin{array}{l}\text { Quantitative } \\
\text { Utility of } \\
\text { Options (Ui) }\end{array}$ & $\begin{array}{l}\text { Ranking } \\
\text { of options }\end{array}$ & Neighborhoods & $\begin{array}{c}\text { Relative } \\
\text { Importance of } \\
\text { Options (Qi) }\end{array}$ & $\begin{array}{l}\text { Quantitative } \\
\text { Utility of } \\
\text { Options (Ui) }\end{array}$ & $\begin{array}{l}\text { Ranking } \\
\text { of options }\end{array}$ \\
\hline 1 & 0.037905 & 42.0777 & 16 & 12 & 0.0338701 & 37.59817 & 20 \\
\hline 2 & 0.070665 & 78.4432 & 5 & 13 & 0.04781 & 53.0818 & 8 \\
\hline 3 & 0.08877 & 98.54965 & 2 & 14 & 0.02987 & 33.1639 & 21 \\
\hline 4 & 0.077198 & 85.69538 & 4 & 15 & 0.046294 & 51.3897 & 9 \\
\hline 5 & 0.080109 & 88.9221 & 3 & 16 & 0.04075 & 45.241 & 15 \\
\hline 6 & 0.03549 & 39.40326 & 19 & 17 & 0.043222 & 47.9796 & 11 \\
\hline 7 & 0.04159 & 46.168 & 13 & 18 & 0.05039 & 55.9471 & 7 \\
\hline 8 & 0.035689 & 39.61724 & 18 & 19 & 0.04141 & 45.96918 & 14 \\
\hline 9 & 0.045543 & 50.556 & 10 & 20 & 0.02719 & 30.1871 & 22 \\
\hline 10 & 0.035911 & 39.8644 & 17 & 21 & 0.041672 & 46.2639 & 12 \\
\hline 11 & 0.0900845 & 100 & 1 & 22 & 0.050693 & 56.2735 & 6 \\
\hline
\end{tabular}


Table7. Physical resilience of neighborhoods based on COPRAS decision making and ranking method.

\begin{tabular}{|c|c|c|c|c|c|c|c|}
\hline \multirow[t]{2}{*}{ Resilience } & \multirow{2}{*}{$\begin{array}{l}\text { COPRAS } \\
\text { coefficient }\end{array}$} & \multicolumn{2}{|c|}{$\begin{array}{c}\text { Number of } \\
\text { neighborhoods }\end{array}$} & \multicolumn{2}{|c|}{$\begin{array}{c}\text { Area of } \\
\text { neighborhoods }\end{array}$} & \multicolumn{2}{|c|}{$\begin{array}{l}\text { Population of } \\
\text { neighborhoods }\end{array}$} \\
\hline & & No & $\%$ & $\mathrm{~m}^{2}$ & $\%$ & People & $\%$ \\
\hline $\begin{array}{l}\text { Very high } \\
\text { resilience }\end{array}$ & $\begin{array}{c}0.0801- \\
0.0900\end{array}$ & 3 & 13.6 & 2423451 & 7.4 & 10414 & 4.1 \\
\hline $\begin{array}{l}\text { High } \\
\text { resilience }\end{array}$ & $\begin{array}{c}0.0706- \\
0.0775\end{array}$ & 2 & 9.1 & 5402967 & 16.5 & 27082 & 10.9 \\
\hline $\begin{array}{l}\text { Average } \\
\text { resilience }\end{array}$ & $\begin{array}{l}0.052- \\
0.0706\end{array}$ & - & 0.0 & - & $0 / 0$ & - & 0.0 \\
\hline $\begin{array}{l}\text { Low } \\
\text { resilience }\end{array}$ & $\begin{array}{c}0.0407- \\
0.052\end{array}$ & 10 & 45.5 & 8924411 & 27.4 & 85141 & 34 \\
\hline $\begin{array}{l}\text { Very low } \\
\text { resilience }\end{array}$ & $\begin{array}{c}0.0271- \\
0.039\end{array}$ & 7 & 31.8 & 15843516 & 48.6 & 127596 & 51 \\
\hline \multicolumn{2}{|c|}{ Total } & 22 & 100 & 32594346 & 100 & 250217 & 100 \\
\hline
\end{tabular}

In COPRAS method, the three neighborhoods 3, 5 and 11 have very high levels of resilience, accounting for 13.6 percent of the total area, as well as 7.4 percent of the total population of Babol with a population of 10414. The neighborhoods 1, 10, 8, 6, 12, 14 and 20 have very low levels of resilience, accounting for 31.8 percent of the total area, as well as 48.6 percent of the total population of Babol with a population of 127596 ( Figure 4 ).

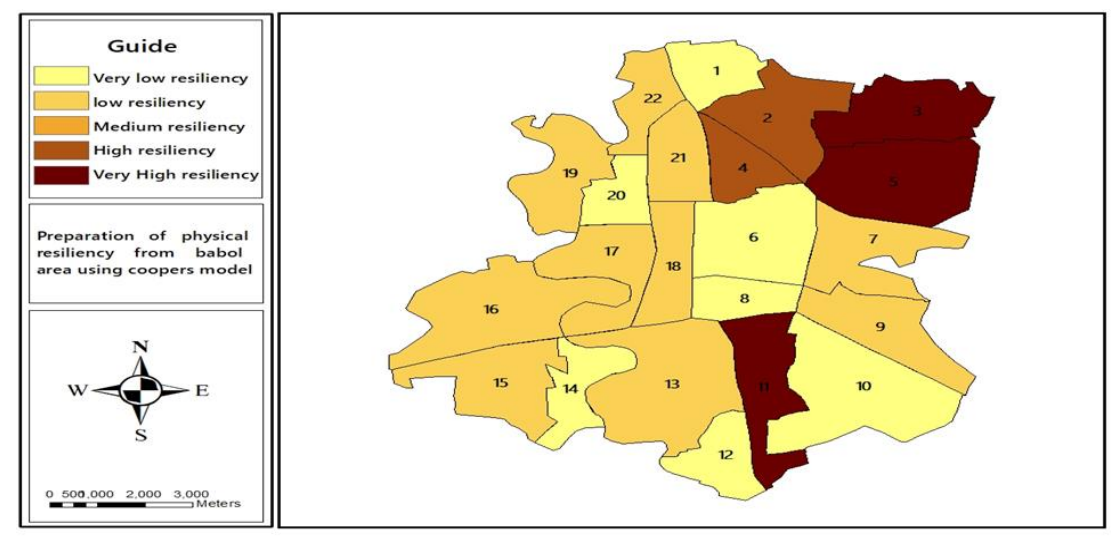

Figure 4. Physical resilience of neighborhoods based on COPRAS decision-making and ranking method.

\section{INTEGRATION MODEL}

Based on the various techniques mentioned above, neighborhoods in Babol might have different rankings. For example, Neighborhood 2 is ranked $5^{\text {th }}$ by TOPSIS methods and $4^{\text {th }}$ by the VIKOR method. In this case, to resolve the differences and conflicts and for consensus in various rankings, it is possible to use the integration method, such as the Statistic, Borda and Copeland. 


\section{STATISTIC METHOD}

In this method, for each option, the mean rank calculated by different methods of multi-criteria decisionmaking is determined, and the options are prioritized accordingly. The statistics are obtained by the TOPSIS, COPRAS and VIKOR for neighborhoods in Babol and the following results are obtained. According to these results, neighborhood 11 has the first and neighborhood 12 has the last rank of resilience.

Table 8. The Statistics of the neighborhoods based on the rank of multi-criteria models.

\begin{tabular}{cccccccccccc}
$\begin{array}{c}\text { Neighborh- } \\
\text { oods }\end{array}$ & $\begin{array}{c}\text { TOPSI } \\
\mathrm{S}\end{array}$ & $\begin{array}{c}\text { COPRA } \\
\mathrm{S}\end{array}$ & $\begin{array}{c}\text { VIKO } \\
\mathrm{R}\end{array}$ & $\begin{array}{c}\text { Statisti } \\
\mathrm{c}\end{array}$ & $\begin{array}{c}\text { Final } \\
\text { rankin } \\
\mathrm{g}\end{array}$ & $\begin{array}{c}\text { Neighborhood } \\
\mathrm{s}\end{array}$ & TOPSIS & $\begin{array}{c}\text { COPRA } \\
\mathrm{S}\end{array}$ & $\begin{array}{c}\text { VIKO } \\
\mathrm{R}\end{array}$ & $\begin{array}{c}\text { Statist } \\
\text { ic }\end{array}$ & $\begin{array}{c}\text { Final } \\
\text { rankin } \\
\mathrm{g}\end{array}$ \\
\hline 1 & 11 & 16 & 3 & 10 & 9 & 12 & 21 & 20 & 19 & 20 & 22 \\
\hline 2 & 5 & 5 & 4 & 4.7 & 3 & 13 & 9 & 8 & 7 & 80 & 6.5 \\
3 & 4 & 2 & 11 & 5.7 & 4 & 14 & 19 & 21 & 15 & 18.3 & 20 \\
4 & 2 & 4 & 48 & 8 & 6.5 & 15 & 14 & 9 & 8 & 10.3 & 10.5 \\
\hline 5 & 6 & 3 & 2 & 3.7 & 2 & 16 & 17 & 15 & 10 & 14 & 14 \\
\hline 6 & 22 & 19 & 5 & 15.3 & 16 & 17 & 18 & 11 & 16 & 15 & 15 \\
7 & 13 & 13 & 22 & 16 & 18 & 18 & 3 & 7 & 17 & 9 & 8 \\
\hline 8 & 20 & 18 & 9 & 15.7 & 17 & 19 & 12 & 14 & 14 & 13.3 & 13 \\
\hline 9 & 8 & 10 & 13 & 10.3 & 10.5 & 20 & 15 & 22 & 20 & 19 & 21 \\
10 & 16 & 17 & 21 & 18 & 19 & 21 & 10 & 12 & 12 & 11.3 & 12 \\
11 & 1 & 1 & 1 & 1 & 1 & 22 & 7 & 6 & 6 & 6.3 & 5 \\
\hline
\end{tabular}

\section{BORDA METHOD}

This method is based on the rule of the majority. In this method, the paired comparison matrix is used for decision-making.

\begin{tabular}{ccccccccccccccccccccccccccccccc}
\hline Neighborhoods & 1 & 2 & 3 & 4 & 5 & 6 & 7 & 8 & 9 & 10 & 11 & 12 & 13 & 14 & 15 & 16 & 17 & 18 & 19 & 20 & 21 & 22 & $\sum \mathrm{c}$ & $\begin{array}{c}\text { Borda } \\
\text { rank }\end{array}$ \\
\hline 1 & 0 & 1 & 0 & 0 & 0 & 1 & 1 & 1 & 0 & 1 & 0 & 1 & 0 & 1 & 1 & 1 & 1 & 0 & 1 & 1 & 0 & 0 & 12 & 10 \\
2 & 0 & 0 & 0 & 0 & 0 & 1 & 1 & 1 & 1 & 1 & 0 & 1 & 1 & 1 & 1 & 1 & 1 & 1 & 1 & 1 & 1 & 1 & 16 & 5.5 \\
3 & 1 & 1 & 0 & 1 & 1 & 1 & 1 & 1 & 1 & 1 & 0 & 1 & 1 & 1 & 1 & 1 & 1 & 1 & 1 & 1 & 1 & 1 & 20 & 2 \\
4 & 1 & 1 & 0 & 0 & 0 & 1 & 1 & 1 & 1 & 1 & 0 & 1 & 1 & 1 & 1 & 1 & 1 & 1 & 1 & 1 & 1 & 1 & 18 & 4 \\
5 & 1 & 1 & 0 & 1 & 0 & 1 & 1 & 1 & 1 & 1 & 0 & 1 & 1 & 1 & 1 & 1 & 1 & 1 & 1 & 1 & 1 & 1 & 19 & 3 \\
6 & 0 & 0 & 0 & 0 & 0 & 0 & 0 & 0 & 0 & 0 & 0 & 1 & 0 & 1 & 0 & 0 & 0 & 0 & 0 & 1 & 0 & 0 & 3 & 19 \\
7 & 0 & 0 & 0 & 0 & 0 & 1 & 0 & 1 & 0 & 1 & 0 & 1 & 0 & 1 & 0 & 1 & 1 & 0 & 1 & 1 & 0 & 0 & 9 & 13 \\
8 & 0 & 0 & 0 & 0 & 0 & 1 & 0 & 0 & 0 & 0 & 0 & 1 & 0 & 1 & 0 & 0 & 0 & 0 & 0 & 1 & 0 & 0 & 4 & 18 \\
9 & 1 & 0 & 0 & 0 & 0 & 1 & 1 & 1 & 0 & 1 & 0 & 1 & 0 & 1 & 0 & 1 & 1 & 0 & 1 & 1 & 1 & 0 & 12 & 10 \\
10 & 0 & 0 & 0 & 0 & 0 & 1 & 0 & 1 & 0 & 0 & 0 & 1 & 0 & 1 & 0 & 0 & 0 & 0 & 0 & 1 & 0 & 0 & 5 & 17 \\
\hline
\end{tabular}




\begin{tabular}{|c|c|c|c|c|c|c|c|c|c|c|c|c|c|c|c|c|c|c|c|c|c|c|c|c|}
\hline 11 & 1 & 1 & 1 & 1 & 1 & 1 & 1 & 1 & 1 & 1 & 0 & 1 & 1 & 1 & 1 & 1 & 1 & 1 & 1 & 1 & 1 & 1 & 21 & 1 \\
\hline 12 & 0 & 0 & 0 & 0 & 0 & 0 & 0 & 0 & 0 & 0 & 0 & 0 & 0 & 0 & 0 & 0 & 0 & 0 & 0 & 1 & 0 & 0 & 1 & 21 \\
\hline 13 & 1 & 0 & 0 & 0 & 0 & 1 & 1 & 1 & 1 & 1 & 0 & 1 & 0 & 1 & 1 & 1 & 1 & 0 & 1 & 1 & 1 & 0 & 14 & 7.5 \\
\hline 14 & 0 & 0 & 0 & 0 & 0 & 0 & 0 & 0 & 0 & 0 & 0 & 1 & 0 & 0 & 0 & 0 & 0 & 0 & 0 & 1 & 0 & 0 & 2 & 20 \\
\hline 15 & 0 & 0 & 0 & 0 & 0 & 1 & 1 & 1 & 1 & 1 & 0 & 1 & 0 & 1 & 0 & 1 & 1 & 0 & 1 & 1 & 1 & 0 & 12 & 10 \\
\hline 16 & 0 & 0 & 0 & 0 & 0 & 1 & 0 & 1 & 0 & 1 & 0 & 1 & 0 & 1 & 0 & 0 & 1 & 0 & 0 & 1 & 0 & 0 & 7 & 15 \\
\hline 17 & 0 & 0 & 0 & 0 & 0 & 1 & 0 & 1 & 0 & 1 & 0 & 1 & 0 & 1 & 0 & 0 & 0 & 0 & 0 & 1 & 0 & 0 & 6 & 16 \\
\hline 18 & 1 & 0 & 0 & 0 & 0 & 0 & 1 & 1 & 1 & 1 & 0 & 1 & 1 & 1 & 1 & 1 & 1 & 0 & 1 & 1 & 1 & 0 & 14 & 7.5 \\
\hline 19 & 0 & 0 & 0 & 0 & 0 & 1 & 0 & 1 & 0 & 1 & 0 & 1 & 0 & 1 & 0 & 1 & 1 & 0 & 0 & 1 & 0 & 0 & 8 & 14 \\
\hline 20 & 0 & 0 & 0 & 0 & 0 & 0 & 0 & 0 & 0 & 0 & 0 & 0 & 0 & 0 & 0 & 0 & 0 & 0 & 0 & 0 & 0 & 0 & 0 & 22 \\
\hline 21 & 1 & 0 & 0 & 0 & 0 & 1 & 1 & 1 & 0 & 1 & 0 & 1 & 0 & 1 & 0 & 1 & 1 & 0 & 1 & 1 & 0 & 0 & 11 & 12 \\
\hline 22 & 1 & 0 & 0 & 0 & 0 & 1 & 1 & 1 & 1 & 1 & 0 & 1 & 1 & 1 & 1 & 1 & 1 & 1 & 1 & 1 & 1 & 0 & 16 & 5.5 \\
\hline$\sum \mathrm{R}$ & 9 & 5 & 1 & 3 & 2 & 17 & 12 & 17 & 9 & 16 & 0 & 20 & 7 & 19 & 9 & 14 & 15 & 6 & 13 & 21 & 10 & 5 & & \\
\hline
\end{tabular}

Table 9. The results of paired comparisons and the number of wins and losses of each factor according to the Borda technique.

\section{COPELAND METHOD}

This method is the modified version of Borda except that in priority, in addition to the number of wins, the number of loses is also calculated for each optionFinally, based on this technique, neighborhood 11 has the highest and neighborhoods 12 and 20 have the lowest ranks of resilience.

Table 10. Prioritization of neighborhoods based on resilience rating by Copeland method.

\begin{tabular}{|c|c|c|c|c|c|c|c|c|c|}
\hline Neighborhoods & $\mathrm{C} \sum$ & $\mathrm{R} \sum$ & $\sum \mathrm{C}-\sum \mathrm{R}$ & $\begin{array}{c}\text { Copeland } \\
\text { rating }\end{array}$ & Neighborhoods & $\mathrm{C} \sum$ & $\mathrm{R} \sum$ & $\sum \mathrm{C}-\sum \mathrm{R}$ & $\begin{array}{c}\text { Copeland } \\
\text { rating }\end{array}$ \\
\hline 1 & 12 & 9 & 3 & 10 & 12 & 1 & 20 & -19 & 21 \\
\hline 2 & 16 & 5 & 11 & 5.5 & 13 & 14 & 7 & 7 & 8 \\
\hline 3 & 20 & 1 & 19 & 2 & 14 & 2 & 19 & -17 & 20 \\
\hline 4 & 18 & 3 & 15 & 4 & 15 & 12 & 9 & 3 & 10 \\
\hline 5 & 19 & 2 & 17 & 3 & 16 & 7 & 14 & -7 & 15 \\
\hline 6 & 3 & 17 & -14 & 19 & 17 & 6 & 15 & -9 & 16 \\
\hline 7 & 9 & 12 & -3 & 13 & 18 & 14 & 6 & 8 & 7 \\
\hline 8 & 4 & 17 & -13 & 18 & 19 & 8 & 13 & -5 & 14 \\
\hline 9 & 12 & 9 & 3 & 10 & 20 & 0 & 21 & -21 & 21 \\
\hline 10 & 5 & 16 & -11 & 17 & 21 & 11 & 10 & 1 & 12 \\
\hline 11 & 21 & 0 & 21 & 1 & 22 & 16 & 5 & 11 & 5.5 \\
\hline
\end{tabular}

\section{INTEGRATION OF THE RESULTS FROM THE STATISTIC, BORDA AND COPELAND}

In this phase, according to the three priority-ranking strategies (Statistic, Borda and Copeland) a consensus is made with a partial ranking. After that, the ranking of the indices is achieved with the help of all three methods, and the results are integrated and the mean is obtained for each neighborhood. Finally, 
each of the neighborhoods is ranked according to the results of the integration method and the final rating at the level of resilience is achieved. According to the table below, the 22 neighborhoods of Babol are at different levels of resilience. Neighborhoods 11, 5, 3 and 2 are at high levels and neighborhoods 12 and 20 are at low levels of resilience.

Table 11. The results of the integration method based on the degree of physical resilience of the neighborhoods.

\begin{tabular}{ccccccc}
\hline Neighborhoods & $\begin{array}{c}\text { Mean } \\
\text { rank }\end{array}$ & $\begin{array}{c}\text { Borda } \\
\text { ranking }\end{array}$ & $\begin{array}{c}\text { Copeland } \\
\text { rating }\end{array}$ & $\begin{array}{c}\text { Total } \\
\text { ranks }\end{array}$ & Statistic & $\begin{array}{c}\text { Final } \\
\text { ranking }\end{array}$ \\
\hline 1 & 9 & 10 & 10 & 29 & 9.7 & 9 \\
2 & 3 & 5.5 & 5.5 & 14 & 4.7 & 4 \\
3 & 4 & 2 & 2 & 8 & 2.7 & 2.5 \\
4 & 6.5 & 4 & 4 & 14.5 & 4.8 & 5 \\
\hline 5 & 2 & 3 & 3 & 8 & 2.7 & 2.5 \\
6 & 16 & 19 & 19 & 54 & 18 & 19 \\
7 & 18 & 13 & 13 & 44 & 14.7 & 14.5 \\
8 & 17 & 18 & 18 & 53 & 17.7 & 17.5 \\
\hline & 10.5 & 10 & 10 & 30.5 & 10.2 & 10.5 \\
10 & 19 & 17 & 17 & 53 & 17.7 & 17.5 \\
11 & 1 & 1 & 1 & 3 & 1 & 1 \\
12 & 22 & 21 & 21 & 64 & 21.3 & 21.5 \\
13 & 6.5 & 7.5 & 8 & 22 & 7.3 & 7 \\
14 & 20 & 20 & 20 & 60 & 20 & 20 \\
15 & 10.5 & 10 & 10 & 30.5 & 10.2 & 10.5 \\
16 & 14 & 15 & 15 & 44 & 14.7 & 14.5 \\
17 & 15 & 16 & 16 & 47 & 15.7 & 16 \\
18 & 8 & 7.5 & 7 & 22.5 & 7.5 & 8 \\
19 & 13 & 14 & 14 & 41 & 13.7 & 13 \\
21 & 21 & 22 & 21 & 64 & 21.3 & 21.5 \\
\hline 2 & 12 & 12 & 12 & 36 & 12 & 12 \\
\hline
\end{tabular}

Table 12. Final physical resilience of 22 neighborhoods of Babol against earthquakes based on the integration model.

\begin{tabular}{|c|c|c|c|c|c|c|}
\hline \multirow[t]{2}{*}{ Resilience } & \multicolumn{2}{|c|}{$\begin{array}{c}\text { Number of } \\
\text { Neighborhoods }\end{array}$} & \multicolumn{2}{|c|}{$\begin{array}{c}\text { Area of } \\
\text { neighborhoods }\end{array}$} & \multicolumn{2}{|c|}{$\begin{array}{l}\text { Population of } \\
\text { neighborhoods }\end{array}$} \\
\hline & No & $\%$ & $\mathrm{~m}^{2}$ & $\%$ & People & $\%$ \\
\hline Very high resilience & 5 & 22.7 & 7826418 & 24 & 37496 & 15 \\
\hline High resilience & 4 & 18.1 & 5617387 & 17.2 & 46283 & 18.5 \\
\hline Average resilience & 4 & 18.1 & 5557875 & 17 & 49912 & 20 \\
\hline Low resilience & 3 & 13.6 & 5567721 & 17.1 & 35833 & 14.3 \\
\hline Very low resilience & 6 & 27.4 & 8024943 & 24.7 & 80709 & 32.3 \\
\hline Total & 22 & 100 & 32594346 & 100 & 250217 & 100 \\
\hline
\end{tabular}




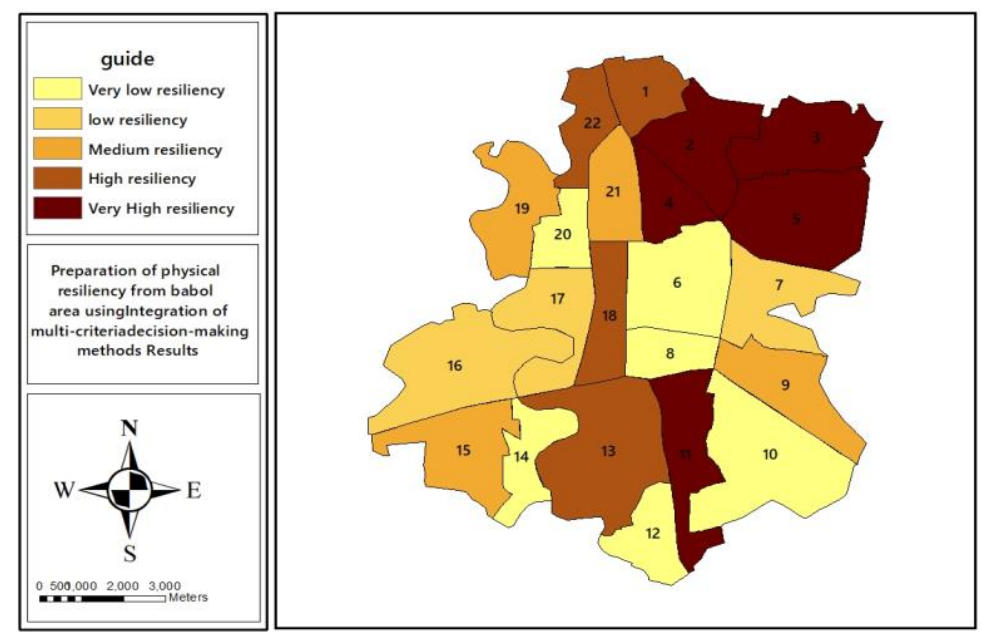

Figure 5. Final physical resilience of 22 neighborhoods of Babol against earthquakes based on the integration model.

The results of TOPSIS, VIKOR and COPRAS for ranking the physical resilience of neighborhoods in Babol show a difference in ranking. Therefore, it can be concluded that the outputs of a single model cannot be reliable because each model can provide different ratings for its indices. Therefore, the results of a model alone are not sufficient. Hence, in order to obtain accurate results, the final evaluation was carried out through the integration model (Statistic, Borda and Copeland). Finally, with the help of GIS software, the final resilience of 22 neighborhoods of Babol was assessed and evaluated (Figure5).

In the final integration of the models used in the integrated method, neighborhoods $11,5,4,3$ and 2 have very high resilience, which comprised $22.7 \%$ of the total population of neighborhoods with a population of 37496 , which is $24 \%$ of the total area of Babol. Statistics show that most of the buildings in these neighborhoods have metal skeletons and plots of less than 100 meters and a population density of less than 100 people per hectare. Buildings are less than 10 years old and the access to open spaces is less than 50 meters. The proximity to medical and relief centers has also put the two neighborhoods in very excellent physical condition.

The Findings of this study show that 4 neighborhoods, 22,18,13,1, which includes $18.1 \%$ of the total neighborhoods with a population of 46,283 people, have excellent physical resilience. The population covers $18.5 \%$ of the total population and $17.2 \%$ of the total area of the city. Field studies and observations show that most of the buildings in these neighborhoods are made of concrete skeletons. Also, most of the parts in these neighborhoods are less than 300 meters and the population density is less than 200 people per hectare.

This study shows that 4 neighborhoods, $21,19,15,9$, which comprise $18.1 \%$ of the total neighborhoods with a population of 49,912 , have moderate resilience. Moreove cover $20 \%$ of the total population and $17 \%$ of the total area of the city. These neighborhoods mainly have relatively open spaces, with adequate electricity and gas networks and relatively low population density. Generally, they have moderate physical resilience.

Surveys show that three neighborhoods, 17,16 , and 7 , which account for $13.6 \%$ of the total population with a population of 35,833 , have low resilience. Also, $14.3 \%$ of the total population with an area of 5567721 square meters, which is $17.1 \%$ of the total area of the city. These neighborhoods have marginal and often old context with undesirable materials. Most of its residents are middle-income 
and low-income and have poor access to security and health services. These three neighborhoods are generally in poor physical resilience.

The findings of this study show that 6 neighborhoods, including 20,14,12,10,8,6, have very low resilience. It also includes 27.4 percent of the total population of 80,709 people, which covers 24.7 percent of the city of Babylon. These neighborhoods were located almost in the central part of the city. Most of their context is old, have low passageways and their average lifespan is more than 50 years. In addition, due to the low open space and high water level, these three neighborhoods are in very Poor physical condition.

\section{CONCLUSION AND RECOMMENDATIONS}

Natural hazards have become one of the main concerns of planners and urban managers in recent years due to the severity and short duration of impact on communities and urban neighborhoods.

With the development of communities and the complexity of the processes within cities, the effects of natural disasters, especially earthquakes, have become widespread, and it is more difficult to reduce and control the vulnerability and increase the resilience of urban communities

Accordingly, the authors studied the resilience situation in the neighborhoods of Babol. The difference between this research and other studies in this field is the use of comprehensive indices in the resilience discussion.

The overall assessment shows that 22 neighborhoods of Babol have different levels in terms of physical resilience to earthquakes. Based on surveys and ranking of neighborhoods using the integration model, neighborhoods $6,8,10,12,14$, and 20 have very low resilience, most of which are located in the central and southern parts of Babol and have high vulnerability to earthquakes. The most important physical parameters in increasing the vulnerability and reducing the resilience of the above-mentioned sites include worn-out texture, non-observance of building standards, poor material, high density of buildings and population and lack of access to open space. The results also show that neighborhoods in the east and southeast have unauthorized context with the majority of low-income and middle-income settlers. Improvement of services such as the establishment of desirable health centers, the development of parks and outdoor areas, the enhancement of relief and security centers are important priorities.

This research also shows that neighborhoods 2, 3, 4, 5 and 11 of Babol have very high resilience against earthquakes. Since most of the buildings in these neighborhoods are renovated, most of the desirable building materials, including steel, iron and brick, have been used. There are also indicators such as access to open spaces and treatment centers, low building density, and distance from hazardous zones. Consideration of physical infrastructure has made these neighborhoods desirable in terms of physical resilience. These neighborhoods were mostly located in the north of the city.

Generally, this study shows that around $46.6 \%$ of the population of Babol lives in high-risk areas with very low levels of resilience, which is significant, and only $33.5 \%$ of the city's population is in low-risk areas with high and very high resilience. According to the framework provided in this research and its applicability, this method can be used to measure and assess the degree of body resilience in other urban areas. According to the results of this research, the following suggestions are presented to improve the resilience:

1.Active urban cooperation in national, regional and international networks and sharing experiences to enhance city resilience and joining the campaign "Urban resilience, my city is becoming prepared". 
2.Applying rules and supervision to reinforce worn-out buildings and increasing the safety factor in new construction sites with priority for earthquakes.

3.Detailed study of the vulnerability of neighborhoods during an earthquake and preparing neighborhood vulnerability maps.

4.Expanding and strengthening scientific and research studies to identify and reduce the risks of natural disasters with earthquake priority.

5.Creating areas for emergency landing and air rescue, especially in downtown neighborhoods $(6,8$ and 18) to accelerate rescue operations.

6.Separating the routes of critical arteries crossing the neighborhoods to reduce the potential hazards during an earthquake.

7.Due to the high resilience of neighborhoods in the northwest, it is suggested the Urban areas to these neighborhoods be developed to avoid overcrowding of other vulnerable neighborhoods.

\section{REFERENCES}

Ahmadiani, J., Sahraian,Z., \& Khosravi., F. (2010). The Role of Factors Affecting Physical Vulnerability of Jahrom City to Earthquake, Journal of Geographical Sciences Applied Research. 17, 121-143.

Alexander, David. (2002). Principles of Emergency and management, oxford University Press.

Allen, R, M. (2007). Earthquake Hazard Mitigation: New Directions and opportunities, university of California Berkeley, Berekeley, CA, USA, 607-647.

Behtash, M., Kinejad, M., Pirbabaie, M., \& Asgari, A.(2013). Evaluating and Analyzing the Resilience Dimensions and Components of Tabriz Metropolitan Area, Fine Arts Journal, 18 (3), 33-42.

Berke, P ., Smith, G., \& Lyles, W. (2012). Planning for Resiliency: Evaluation of state Hazard Mitigation plans under the Disaster Mitigation Act. Nat Hazards Rev. 13(2), 139-149.

Birkman, J. (2006). Measuring vulnerability to Natural Hazard: Towards Disaster Resilience Societies. United Nations university press, Tokyo.

Carreno, M., Cardona., O., Barabat, A., Suarez, D., Perez, m.,\& Narvaez, D .(2017).Holistic Disaster Risk Evaluation for the urban Risk. Management plan of Manizales, Colombia, int Disaster Risk Sci. 8, 258-269.

Carreno. M., Cardona, O., \& Barbat, A. (2012). New methodology for Urban seismic risk assessment from a holistic perspective. Bull Earhquake Eng. 10, 547-565.

Cutter, S ., Barnes, L., Berry, M., Burton, C ., Evans , E ., Tate, E., \& Webb , J. (2008). A Place-based model for understanding Community resilience to natural disasters, Global Environmental Change.18, 598-606.

Folke, C. (2006). Resilience: The emergence of a perspective for social

ecologicalsystems analyses. Global Environmental Change.16(3), 253-267.

Ghanbari, A., Maleki,M., Ghasemi,M .(2013).Assessing the vulnerability of cities to earthquake hazard case study: Tabriz, Geography and environmental hazards. 5, 21-35.

Godschalk, D.R. (2003). Urban hazard mitigation: creating resilient cities. Natural hazards review. 4 (3), 136-143.

Gunderson, L. (2010). Ecological and human community resilience in response to natural disasters. Ecology and society. 15 (2), 323-331.

Habibi, K., Javanmardi, K. (2012). Analysis of urban context instability and zoning of earthquake vulnerability using GIS \& AHP (Case Study: Part of Central Core of Sanandaj), Arman Shahr Journal of Architecture and Urban Development. 11, 293-305.

Heming way, R., Gnawan, O. (2018). The Natural Hazards partnership: An public- sector collaboration across the UK for natural hazard disaster risk reduction, International Journal of Disaster Risk Reduction. 27, 499-511.

Holing, C. S. (1973). Resilience and stability of Ecological systems, Annual Review of Ecology and systematies. 1, (4) ,1-23. 
Ibrahimzadeh, I., Maleki, S., \& Hatami, D. (2014). Evaluation of Safety in Urban Parks, Case Study: Izeh City Parks, Journal of Urban Research and Planning. 19, 57-72.

Islamlou. M., Mirmoghtadee. M. (2016). Evaluation of urban Resiliency in physico structural Dimension of Karaj Metropolis. Space ontology International Journal. 6(1), 37-46.

Kimhi, S.(2014). Levels of resilience: Associations among indidual, community, and national resilience. Journal of health Psyschology .21(2), 164-170.

Klien, R. J. T., Nicholls, R. J., \& Thomalla, F. (2003). Resilience to natural hazards: How useful is this concept. Environmental Hazards. 5, 35-45.

Krimer, A., Arnold, M., Carlin, A. (2003). Building Safer cities, the future of Disaster Risk, Disaster Risk angerment series.The International Bank for Reconstruction and Development. 3, the world bank.

Maleki. S.,Amampoor. S., Safaeipoor. M.,Poormousavi, N., \& Movedat, E. (2017). Evaluation of physical Resilience of cities against Earthquake using programming model case study: Ilam,, Journal of physical Development planning. 2 (1), 9-20.

Martinelli A., Cifani G. (2008). Bulding Vulnerability Assessment and Damage scenarios incelano (Italy) using a Quick survey Data- based methodology, Soil Dynamics and Earthquake Engineering. 28, 875-889.

Mayunga, J. S. (2007). Understanding and Applying the concept of community Disaster Resilience: A capital- based Approach. A dreft working paper prepared for the summer Academy for social Vulnerability and Resilience. Building, 21-22 july, munich, Germany.1, 1-16.

McEntire, D., Fuller, Ch., Johndton, Ch.W., \&Weber,R. (2002). A comparison of disaster paradigms: The search for a holistic policy guide, Public Administration Review.62(3), 267-281.

Meerow, S., Newell. J. P., \&Stults, M.(2016). Defining Urban resilience: A review, Landscape and Urban planning. 147, 38-49.

Mishra, A., Thing, R. (2019). Structural Features for Earthquake-Resistant Load-Bearing Residential Buildings in Nepal. Journal of Advanced Research in Geo Sciences \& Remote Sensing. 6,1-16.

Mitchell, T., Harris, k.(2012). Resilience: A risk management approach. Overseas Development Institute. ISSN 1756-7610, 1-7.

Mohammadi, M. (2014). Karaj Urban Permeability Assessment of Hazards, Journal of space planning and development. 18 (3), 53-77.

Omand, D. (2005). Developing National Resillence, RUSI Journal. 50 (4), 14-18.

Rashed, T., Weeks, J. (2003). Assessing vulnerability to earthquake hazards through spatial multicriteria analysis of urban areas. International journal of Geographical Information Scince.1, (6) ,547-576.

Robat mili, R.,Hosseini, K., \&Izadkhah, Y.(2018). Developing a Holistic Model for earthquake Risk Assessment and Disaster Management Interventions in Urban Fabrics. International Journal of Disaster Risk Reduction. 27, 355365.

Rezaei, M., Rafieian, M., \& Hosseini.,M.(2015). Measurement and Evaluation of the physical Resilience of Urban community againet earthquake (Case study: Tehran's Neighborhoods), Journal of Human Geography Research. 470 (4), 609-623.

Rose, A .(2004). Defining and measuring economic resilence to disasters. Disaster Prevention and Management. 13, 307-314.

Sarvar, H., Kashani Asl, A.(2016). Assessment of Physical Vulnerability of Ahar City gainst Earthquake Crisis, Journal of Environmental Management Quarterly. 9 (34), 87-108.

Shokri, P .(2017). Spatial Analysis of Resilience of Babol Regions to Environmental Hazards, Journal of Physical Development Planning. 2 (2), 27-44.

Takewaki, I .(2013). Toward greater building earthqueake resilience using concept of critical excitation: A review, sustainable cities and society. 9, 39-53.

Tucker, B.E.(1994). Some Remark Concerning Worldwide Earthquake Hazard and Earthquke Hazard mitigation. Issues in urban Earthquake Risk. 1-10.

Varesi, H., Amir Akbari, M.(2012). Investigating Residential Buidings Resilience to earthquakes, case study: Hamedan, Haft Hesar Magazine. 1, 45-60. 
ZangiAbadi, A., Rezaei, M., Momeni Shahraki, M., \&Mirzaei, S.(2013). Assessment of vulnerability of earthquake crisis central part of Iranian metropolitan cities using IHWP model (Case study: Isfahan District 3), Journal of Space Geography. 8, 137-156.

Zhou, L., Wu, x; Xu., \&Z; Fujita. (2018). Emergency decision making for natural disasters: An overview, International Journal of Disaster Risk Reduction. 27, 567-576.

Ziyari,K.,Dehcheshmeh,M.,Pour hmad, A., \&Ghalibaf, M,B.( 2012). Prioritizing immunization of the old context of Karaj metropolitan area using multi-criteria evaluation model, Journal of Human Geography Research. 79, 1-14. 